\title{
Effect of Encapsulated Amylase Enzyme on the Performance and Digestibility of Energy in Broilers
}

\author{
R. Purshotham Naik ${ }^{1} *$, A. Rajashekher Reddy ${ }^{1}$, K. Kondal Reddy ${ }^{2}$, and J. Jyothi ${ }^{3}$ \\ ${ }^{1}$ Department of Poultry Science, College of Veterinary Science Rajendranagar, \\ Hyderabad, 30, India \\ ${ }^{2}$ Department of Livestock Products Technology, CVSc- Rajendranagar, Hyderabad-30, India \\ ${ }^{3}$ Department of Veterinary Medicine, C.V.Sc, Korutla, India
}

*Corresponding author

\author{
A B S T R A C T
}

Keywords

Amylase,

Encapsulation, Digestibility, FCR.

Article Info

Accepted:

20 February 2017

Available Online:

10 March 2017
Enzymes are thermo-labile and they may lose activity during pelletization of feed. Encapsulation/ coating of enzyme is important for the stability of feed enzymes. Effect of feeding encapsulated amylase enzyme in corn soy pelleted diets on the performance of broilers was studied. Amylase enzyme were encapsulated with sodium alginate and included in diets at $2000 \mathrm{IU} / \mathrm{kg}$. Two hundred day old broiler chicks were randomly distributed into four treatments, with 10 replicates of 5 birds in each replicate. Two diets control and basal diets were formulated for starter and finisher. Basal diet (BD) was reduced by $115 \mathrm{k}$.cal $\mathrm{ME}$ compared to control diet. Addition of uncoated and coated amylase enzyme to basal diets did not show significant $(\mathrm{P}<0.05)$ improvement in body weight gain and feed intake, but there was significant improvement in FCR and digestibility of energy for uncoated and coated amylase enzyme compared to control. Thus it can be concluded that addition of amylase enzyme has resulted in improved performance through better FCR, digestibility and reduced abdominal fat.

\section{Introduction}

Feeding of poultry is a major component that decides the profit. Corn and soyabean meal are the major ingredients used in the preparation of poultry feed. Pelleting is associated with positive effects by improving feed efficiency and growth performance of broilers. These improvements are attributed to decreased feed wastage, higher bulky, nutrient density, no selective feeding, decreased feed segregation, thermal modification of starch and protein, improved palatability and inactivation of enzyme inhibitor (Piesker, 2006). Exogenous enzyme play a key role in digestive process, but these added must be active under physiological condition prevailing in the animal digestive tract in order to realize their benefits. Activity of enzymes is reduced /lost during pellet processing involving temperature and steam (Jensen, 2000). The combination of heat and humidity may cause a severe inactivation of enzymes thus to overcome this problem coating of enzyme with a 
barrier/encapsulation is one approach to prevent contact of the enzyme with steam, moisture and harsh condition during pelleting.

The coated/encapsulated may survive the pelleting process well. In view of the above, present study was conducted to evaluate the supplementation of encapsulated amylase enzyme effect on the performance of broilers (FCR, Body weight gain, Feed intake), live ability, carcass parameters, digestibility, and serum protein.

\section{Materials and Methods}

Two hundred day old commercial broiler chicks were randomly distributed into 4 treatments with 10 replicates of 5 birds in each replicate, which were reared for a period of 6 weeks under uniform managemental conditions.

On day 1, chicks were wing banded and housed in wire-floored stainless battery brooders. Birds were immunized for Marek's disease at hatchery, New Castle disease (ND) at $7^{\text {th }}$ day and $21^{\text {st }}$ day of age with Lasota vaccine and infectious bursal disease at $14^{\text {th }}$ day of age with Georgia strain vaccine.

A corn soya starter (0-3wks) and finisher (4$6 \mathrm{wks}$ ) pelleted diets were formulated (NRC 1994) for four treatments i.e T1-Control diet, T2-Basal diet (BD) (with $115 \mathrm{kcal}$ less $\mathrm{ME}$ compared to control diet), T3- BD+ uncoated amylase enzyme and T4-BD+ coated amylase enzyme (Table 1,2), amylase enzyme was added at $2000 \mathrm{IU} / \mathrm{kg}$ feed.

All the treatments were offered ad-libitum feed and water for 1-42 days.

Weekly body weights, feed intake and weight of feed residue was recorded to calculate the weekly body weight gain and FCR.

\section{Encapsulation of enzymes (Extrusion Technique)}

Coating of enzymes was done by using alginate standard method (Krasaekoopt et al.,2003) amylase enzymes was added into a hydrocolloid solution (alginate) and then the cell suspension was extruded through a syringe needle to form droplets, which freefall into a setting bath containing hardening solution $\mathrm{CaCl} 2$. Concentration of alginate was $1 \%$ to form a gel with $0.5 \mathrm{M} \mathrm{CaCl} 2$. Uniform size and shape beads were obtained with alginate coat over enzymes for use in experimental diets

\section{Metabolic trial}

A metabolic trial was conducted for three days after 42 days of trial by keeping 2 birds in each replicate. All the birds were fasted to ensure emptying of gastrointestinal tract. Weighed quantity of feed was offered for three days. Litter trays were covered with plastic sheets under each cage cells and were replaced with new plastic sheet very next day. Faecal samples were collected daily carefully by separating feathers, scales and traces of feed. All the faecal samples were oven dried at $60^{\circ} \mathrm{C}$ for $24 \mathrm{hrs}$ and weighed to record the faecal output on dry matter basis. Representative samples of feed and left over feed were collected and dried at $100 \pm 5^{\circ} \mathrm{C}$ for 8-10 hrs to estimate the dry matter intake. Analysis of crude protein and gross energy of dried excreta as carried as per AOAC (2005).

\section{Slaughter and serum parameters}

At the end of experiment 2 birds per replicate were slaughtered for carcass parameters like dressing percentage, heart, gizzard, liver weighs and abdominal fat weight. Blood samples were collected in clean sterilized glass tubes for serum collection and the serum was stored in eppendorf tubes at $-20^{\circ} \mathrm{C}$ for 
estimation of biochemical constituents i.e., total protein (Reinhold, 1953).

\section{Statistical analysis}

The data were subjected to statistical analysis by applying one way ANOVA as per procedures of Snedecor and Cochran (1980). The differences between the means were tested by significance using Duncan's multiple range test (Duncan, 1955).

\section{Results and Discussion}

\section{Body weight gain}

Supplementation of coated amylase enzyme preparation in corn soya low energy basal diet resulted $(\mathrm{P}<0.05)$ significant increase in body weight gain by $4.1 \%$ during $0-3 \mathrm{wks}$ for coated amylase and numerical increase in body weight gain by $3.1 \%$ is observed in supplementation of uncoated amylase enzyme when compared to basal diet. During 0-6 wks period no significant improvement was observed in enzyme supplemented groups when compared to low energy basal diets, and this is in agreement with parkany-gyarfas (1975), who found a 3.6\% improvement in body weight gain and $4.0 \%$ improvement in feed utilization in male turkey when corn soybean meal diets was supplemented with $\alpha$ amylase and similar results were observed by Ritz et al, (1995). The improvement in body weight gain during 0-3wks might be due to beneficial effect of supplemental exogenous enzyme as the production of endogenous enzymes during early chick stage is inadequate due to poor development of digestive system and which was reported to mature with increase in age of the bird. (Olukosi et al, 2007).

\section{Feed intake and FCR}

Supplementation of enzyme resulted no significant increase in feed intake during 0$3 w k, 4-6 w k$ and 0-6wks period when compared to low energy basal diet and this was in agreement with cowienson and Ravindran (2008) who reported that supplementation of enzyme in corn soya diet resulted no improvement in feed intake in broilers. Supplementation of enzyme resulted in improvement of FCR. Coated amylase showed better when compared to control and basal diets during 4-6wks and 0-6wks (Table3). Significant improvement in FCR for coated (1.723) and uncoated (1.731) when compared to control (1.798) and low energy basal diet (1.772) during 0-6wks period and this was in agreement with srinath et al (2012). Improvement of FCR in enzyme supplemented diets might be due to better digestibility of nutrients. The digestibility of starch with amylase enzyme may explain the improvement in FCR in our work. This was supported by Ritz et al (1995) who reported that amylase enzyme supplementation increased the length of villi with in jejunal and ileal section in $3 \mathrm{wk}$ old turkey poult fed corn soya-bean meal diet. The increase in area suggested by increase in villus length and that might have enhanced the nutrient absorption and there by improved the nutrient digestibility.

Table.1 Treatment groups and diets

\begin{tabular}{cl}
\hline Treatment groups & Treatment diets \\
\hline T1 & Control \\
T2 & Basal diet $(115 \mathrm{kcal}$ less ME of control) \\
T3 & Basal + uncoated amylase \\
T4 & Basal + coated amylase \\
\hline
\end{tabular}


Table.2 Ingredient ( $\mathrm{g} / \mathrm{kg}$ ) and nutrient composition (\% dry matter) of basal diet fed to broilers

\begin{tabular}{|c|c|c|c|c|}
\hline \multirow[t]{2}{*}{ Ingredients } & \multicolumn{2}{|c|}{ Starter(0-3 wks) } & \multicolumn{2}{|c|}{ Finisher(4-6 wks) } \\
\hline & Control diet & Basal diet & Control diet & Basal diet \\
\hline Maize & 554.08 & 582.67 & 628.33 & 655.47 \\
\hline Soya bean meal & 383.04 & 377.45 & 303.82 & 298.75 \\
\hline DORB & 0.00 & 0.80 & 0 & 0 \\
\hline Salt & 3.99 & 3.99 & 4.0 & 4.0 \\
\hline Dicalcium phosphate & 19.55 & 19.42 & 17.12 & 17.03 \\
\hline Shell grit & 4.52 & 4.66 & 4.48 & 4.57 \\
\hline DL-Methionine & 2.66 & 2.66 & 2.21 & 2.19 \\
\hline $\mathrm{AB}_{2} \mathrm{D}_{3} \mathrm{~K}^{1}$ & 0.13 & 0.27 & 0.2 & 0.2 \\
\hline B complex ${ }^{2}$ & 0.13 & 0.13 & 0.15 & 0.15 \\
\hline Choline chloride & 0.93 & 1.06 & 1.0 & 1.0 \\
\hline Toxin Binder & 2.00 & 2.00 & 2.0 & 2.0 \\
\hline Trace mineral mixture ${ }^{3}$ & 0.93 & 1.06 & 1.0 & 1.0 \\
\hline Antibiotic(chlortetracycline) & 0.53 & 0.53 & 0.5 & 0.5 \\
\hline Cocciodiostat & 0.53 & 0.53 & 0.5 & 0.5 \\
\hline L-Lysine & 0.53 & 0.67 & 0.99 & 1.08 \\
\hline Vegetable oil & 23.81 & 0.00 & 33.7 & 11.56 \\
\hline \multicolumn{5}{|c|}{ Nutrient composition (calculated) ${ }^{*}$} \\
\hline M.E (kcal/kg) & 2900 & 2785 & 3100 & 2985 \\
\hline Protein $\%$ & 22 & 22 & 19 & 19 \\
\hline Calcium \% & 0.8 & 0.8 & 0.8 & 0.8 \\
\hline Available phosphorus $\%$ & 0.45 & 0.45 & 0.4 & 0.4 \\
\hline Lysine \% & 1.25 & 1.25 & 1.097 & 1.097 \\
\hline Methionine \% & 0.56 & 0.56 & 0.51 & 0.51 \\
\hline
\end{tabular}

Table.3 Effect of uncoated and coated amylase enzyme on body weight gain, feed intake, FCR

\begin{tabular}{lllllccccc}
\hline & \multicolumn{3}{c}{$\mathbf{0 - 3}$ wks } & \multicolumn{3}{c}{ 4-6wks } & \multicolumn{3}{c}{ 0-6 wks } \\
\hline & $\begin{array}{l}\text { B.wt } \\
\text { gain }\end{array}$ & $\begin{array}{c}\text { Feed } \\
\text { intake }\end{array}$ & FCR & $\begin{array}{l}\text { B.wt } \\
\text { gain }\end{array}$ & $\begin{array}{c}\text { Feed } \\
\text { intake }\end{array}$ & FCR & $\begin{array}{c}\text { B.wt } \\
\text { gain }\end{array}$ & $\begin{array}{c}\text { Feed } \\
\text { intake }\end{array}$ & FCR \\
\hline $\begin{array}{l}\text { T1-Control } \\
\text { T2-Basal diet (BD) }\end{array}$ & 617.7 & 973.1 & $1.575^{\mathrm{a}}$ & $1276^{\mathrm{a}}$ & $2431^{\mathrm{a}}$ & $1.906^{\mathrm{c}}$ & $1894^{\mathrm{a}}$ & $3405^{\mathrm{a}}$ & $1.798^{\mathrm{b}}$ \\
$\begin{array}{l}\text { T3-BD+uncoated } \\
\text { amylase }\end{array}$ & $599.1^{\mathrm{b}}$ & 968.4 & $1.616^{\mathrm{b}}$ & $1201^{\mathrm{b}}$ & $2221^{\mathrm{b}}$ & $1.850^{\mathrm{b}}$ & $1800^{\mathrm{b}}$ & $3189^{\mathrm{b}}$ & $1.772^{\mathrm{b}}$ \\
$\begin{array}{l}\text { T4-BD+coated } \\
\text { amylase }\end{array}$ & $617.9^{\mathrm{ab}}$ & 965.8 & $1.563^{\mathrm{a}}$ & $1228^{\mathrm{ab}}$ & $2229^{\mathrm{b}}$ & $1.816^{\mathrm{ab}}$ & $1846^{\mathrm{ab}}$ & $3194^{\mathrm{b}}$ & $1.731^{\mathrm{a}}$ \\
$\begin{array}{l}\text { SEM } \\
\text { p-value }\end{array}$ & $623.7^{\mathrm{a}}$ & 993.2 & $1.593^{\mathrm{ab}}$ & $1231^{\mathrm{ab}}$ & $2203^{\mathrm{b}}$ & $1.790^{\mathrm{a}}$ & $1854^{\mathrm{ab}}$ & $3196^{\mathrm{b}}$ & $1.723^{\mathrm{a}}$ \\
\hline
\end{tabular}

Values bearing different superscripts within a column are significantly $(\mathrm{P}<0.05)$ different 
Table.4 Effect of uncoated and coated amylase enzyme on dressing yield, giblet weight and fat weight (percentage)

\begin{tabular}{lccccc}
\hline Diets & Dressing yield \% & Heart wt \% & Gizzard wt \% & $\begin{array}{c}\text { Liver } \\
\%\end{array}$ & $\begin{array}{c}\text { Fat wt } \\
\%\end{array}$ \\
\hline $\begin{array}{l}\text { T1-Control } \\
\text { T2-Basal diet (BD) }\end{array}$ & 71.91 & 0.438 & 1.952 & 1.700 & $1.739^{\mathrm{a}}$ \\
T3-BD+uncoated amylase & 71.47 & 0.409 & 1.869 & 1.704 & $1.550^{\mathrm{b}}$ \\
& & 0.438 & 1.985 & 1.744 & $1.267^{\mathrm{c}}$ \\
T4-BD+coated amylase & 71.98 & 0.465 & 1.819 & 1.792 & $1.262^{\mathrm{c}}$ \\
SEM & & & & & \\
p-value & 0.1712 & 0.0106 & 0.0360 & 0.0291 & 0.0373 \\
& 0.322 & 0.344 & 0.352 & 0.664 & 0.000
\end{tabular}

Values bearing different superscripts within a column are significantly $(\mathrm{P}<0.05)$ different

Table.5 Effect of uncoated and coated amylase enzyme on serum protein

\begin{tabular}{lc}
\hline Diets & Serum protein $(\mathrm{g} / \mathrm{dl})$ \\
\hline Control & 3.395 \\
Basal diet & 3.279 \\
Basal +uncoated amylase & 3.300 \\
Basal +coated amylase & 3.327 \\
SEM & 0.0249 \\
p-value & 1.028 \\
\hline earing different superscripts within a column are significantly (P<0.05) different
\end{tabular}

Table.6 Effect of uncoated and coated amylase enzyme on digestibility of protein and Energy

\begin{tabular}{lccc}
\hline & & \multicolumn{2}{c}{ Digestibility \% } \\
\hline Diet & Dry matter & Crude protein & Energy \\
\hline Control & 66.47 & $63.63^{\mathrm{a}}$ & $64.10^{\mathrm{bc}}$ \\
Basal diet & 65.21 & $61.18^{\mathrm{b}}$ & $63.53^{\mathrm{c}}$ \\
Basal +uncoated amylase & 66.92 & $61.12^{\mathrm{b}}$ & $65.48^{\mathrm{ab}}$ \\
Basal +coated amylase & 67.57 & $62.18^{\mathrm{b}}$ & $66.40^{\mathrm{a}}$ \\
SEM & 0.423 & 0.300 & 0.368 \\
p-value & 0.255 & 0.003 & 0.013 \\
\hline
\end{tabular}

Values bearing different superscripts within a column are significantly $(\mathrm{P}<0.05)$ different

Livability and carcass characteristics

Supplementation of uncoated and coated amylase enzyme to basal diet did not show significance difference on livability (Rao et al, 2003) and dressing percentage in broilers (Table 4) compared to control diet and basal diet. But addition of both uncoated and coated 
amylase enzyme showed significant in reduction in abdominal fat when compared to basal and control and the results are in agreement with Garipoglu et al (2006). Abdominal fat is not only a loss, but also it represents added expense for the effluent treatment. Visceral organ weights (Liver, heart, and gizzard) were un-affected in present study with enzyme supplementation and these results are in agreement with Ramesh and chandrasekaran (2011) who reported that there is no significant difference in weights of liver, heart, and gizzard.

\section{Serum protein}

Addition of uncoated (3.300) and coated amylase enzyme (3.327) to basal diet did show a significant improvement in total serum protein level (Table 5) compared to low energy basal diet (3.279) and control (3.395). Abudabos (2010) reported that addition of enzymes to corn-soy based diets showed a significant increase in serum total protein when tomoko a commercial enzyme supplement which contained acidic protease, amylase, pectinase, glucoamylase and cellulose. The improvement in total serum protein might be due to presence of protease in the product that might have increased the serum protein and this way protease is involved in the digestibility of protein and increasing the total serum protein.

\section{Digestibility of protein and energy}

Supplementation of uncoated and coated amylase enzyme to low energy basal diet showed an improvement in energy digestibility by $1.95 \%$ and $2.87 \%$ respectively (Table 6). This improvement in digestibility by adding exogenous enzyme might have unlock the encapsulated starch molecules by solubilizing the cell wall structure and increasing accessibility to digestive enzymes, thus further enhancing the nutrient availability for growth as reported by Hesselman and Aman (1986). Therefore, the significant improvement in protein and GE digestibility observed for broilers fed the corn soyabean diets could result mainly from disruption of the cell wall matrix of soyabean, leading to the release of structural starch and protein (Yu and Chung, 2004). Marsmann et al (1997) also found that supplementation of soybeans with protease and carbohydrase enzymes, individually and in combination improved CP digestion and that the carbohydrase improved the non-starch polysaccharide digestibility of soybean meal. They suggested that the carbohydrase that they have used also exhibited protease activity, supporting the observation by Pack et al (1998).

From the present study it can be concluded that amylase enzyme supplementation has resulted in improved performance through better FCR and digestibility. Alginate process of coating needs to be further investigated for thermal stability and appropriate release of enzymes in the digestive tract.

\section{References}

Abudabos, A. 2010. Enzyme supplementation of corn-soybean meal diets improves performance in broiler chicken. International Journal of Poultry Science, 9(3), 292-297.

AOAC. 2005. Official Methods of Analysis of Association of official Analytical chemist $18^{\text {th }}$ Edition (Virginia, USA, Association of official Analytical chemists).

Cowieson A J and Ravindran V. 2008. Effects of exogenous enzymes in maize-based diets varying in nutrient density for young broilers: growth performance and digestibility of energy, minerals and amino acids. British Poultry Science 49:37-44

Duncan D B. 1955. Multiple ' $\mathrm{F}$ ' test, Biometrics 1: 142.

Garipoglu, A. V., Saricicek, B. Z., \& Kilic, U. (2006). Effects of the commercial enzyme 
supplementation to the rations on broiler performance. Asian J. Anim. Vet. Adv, 1(1), 42-48.

Hesselman, K., \& Åman, P. (1986). The effect of $\beta$-glucanase on the utilization of starch and nitrogen by broiler chickens fed on barley of low-or high-viscosity. Animal Feed Science and Technology, 15(2), 8393.

Jensen, L. S. (2000). Influence of pelleting on the nutritional needs of poultry. AsianAustralasian Journal of Animal Sciences, 13(Special iss.), 35-46.

Krasaekoopt W, Bhandari B and Deeth H. 2003. Evaluation of encapsulation techniques of probiotics for yoghurt. Int Dairy J 13:3-13.

Marsman G J, Gruppen H, Vander poul A F, Kwakkel R P, Verstegen $\mathrm{M} \quad \mathrm{W}$ and Voragen A G. 1997. The effect of thermal processing and enzyme treatments of soybean meal on growth performance, ileal nutrient digestibilities, and characteristics in broiler chicks. Poultry Science 76: 864872.

National Research Council (1994) Nutrient requirements of poultry, $9^{\text {th }}$ edition, National Academy Press, Washington.

Olukosi, O. A., Cowieson, A. J., \& Adeola, O. (2007). Age-related influence of a cocktail of xylanase, amylase, and protease or phytase individually or in combination in broilers. Poultry Science, 86(1), 77-86.

Pack, M., Bedford, M., \& Wyatt, C. (1998). Feed enzymes may improve corn, sorghum diets. Feedstuffs, 70(5), 18-19.

Peisker, M. (2006). Feed processing-Impacts on nutritive value and hygienic status in broiler feeds. In Proceedings os Australian
Poultry Science Symposium (pp. 7-16).

Ramesh, J., Chandrasekaran, D., \& Natarajan, A. (2011). Effect of enzyme supplementaion on digestibilty and metabolizability of nutrients in cockerels. Indian Journal of Animal Research, 45(2), 143-147.

Rao M H, Reddy V R, \& Reddy V R. 2003. Effect of commercial enzymes on the performance of broilers. Indian Journal of Poultry Science, 38(3), 291-293.

Reinhold J G. 1953. Standard methods of clinical chemistry C, (Ed.) Rynner, M, New York, Academic Press pp 88.

Ritz, C. W., Hulet, R. M., Self, B. B., \& Denbow, D. M. (1995). Growth and intestinal morphology of male turkeys as influenced by dietary supplementation of amylase and xylanase. Poultry Science, 74(8), 1329-1334.

Snedecor G W and Cochran W G. 1994. Statistical methods, 8th ed., (Iowa State University Press, Ames, Iowa, USA).

Srinath K, Ravinder Reddy V, Kondal Reddy K, Mallikarjun P V R, Chinni Preetam V and Reddy M R. 2012. Effect of supplementation of corn soya pelleted diets with capsulated feed enzymes on performance of broilers. International Journal of Food, Agriculture and Verterinary Sciences Vol 2(2):115-127.

Yu, B., \& Chung, T. K. (2004). Effects of multiple-enzyme mixtures on growth performance of broilers fed corn-soybean meal diets. The Journal of Applied Poultry Research, 13(2), 178-182.

\section{How to cite this article:}

Purshotham Naik, R., A. Rajashekher Reddy, K. Kondal Reddy, S.V. Rama Rao, Jyothi, J. 2017. Effect of Encapsulated Amylase Enzyme on the Performance and Digestibility of Energy in Broilers. Int.J.Curr.Microbiol.App.Sci. 6(3): 2098-2104. doi: https://doi.org/10.20546/ijcmas.2017.603.239 